\title{
Stress among Nurses in a Tertiary Care Hospital
}

\author{
Rajeswari. $\mathrm{H}^{1 *}$, Dr. B. Sreelekha ${ }^{2}$
}

\section{ABSTRACT}

Stress is a part and parcel of human lifestyle. Stress is a bodily or mental tension resulting from factors that tend to alter an existent equilibrium. Nursing is generally perceived as demanding profession. Along with the increased demand and progress in the nursing profession, stress among the nurses has also increased. The study is carried out with the objectives to assess the level of stress among nurses and to associate the level of stress among nurses with their socio demographic variables. METHODS: Cross sectional research design was adopted.200 nurses working in selected tertiary care hospital were selected by using probability simple random sampling technique. Data was collected by using modified stress inventory. RESULTS: The study revealed that among 200 samples 2(1\%) had mild stress, 79(39.5\%) had moderate stress and $119(59.5 \%)$ had severe stress. In associating the sociodemograpic variables with the level of stress, the variables like age, sex, religion, marital status, educational qualification, designation, area of working, programme attended related to stress, relaxation technique used have no significant association at the level of $\mathrm{p}<0.05$ where as variables income, years of experience, area of living have significant association with level of stress at the level of $\mathrm{p}<0.001 \& \mathrm{p}<0.20$. CONCLUSION: The study concludes that majority of the nurses have stress. It is also found that stress due to work organization and inter personal relationship at work is harder which adds up to the stress. It is evident in the present study that younger age group and women were commonly affected with severe stress .Income earned and place where they live also influences the stress. It is recommended to implement strategies for reducing stress and to organize stress management programme.

Keywords: Stress, Workload, Nurses, Coping

Stress is a part and parcel of human lifestyle. Stress is a bodily or mental tension resulting from factors that tend to alter an existent equilibrium .It is a motivating for achieving anything in the life it is an acknowledged truth that all human being are forced to undergo different kinds of stressors in their life time.

\footnotetext{
${ }^{1}$ Professor, Narayana College of Nursing, Chinthareddypalem, Nellore, Andhrapradesh

${ }^{2}$ Reader, Sri Ramachandra College of Nursing, Sri Ramachandra University, Porur, Chennai *Responding Author (C) 2016 I Rajeswari H, B Sreelekha; licensee IJIP. This is an Open Access Research distributed under the terms of the Creative Commons Attribution License (http://creativecommons.org/licenses/by/2.0), which permits unrestricted use, distribution, and reproduction in any Medium, provided the original work is properly cited.
} 


\section{Stress among Nurses in a Tertiary Care Hospital}

Stress has been labeled as a precursor to an outcome, and a way of handling situations. Lazarus advocated a psychological view in which stress is "a particular relationship between the person and the environment that is appraised by the person as taxing or exceeding his or her resources and endangering his or her well-being”.

Stress is not innately harmful, but it depends on the thinking, perception and interpretation of those stimuli which signify the experience and concludes whether actions are to be out looked as frightening or positive. Individuality too persuades the stress association because what may be overburden to one person may be exciting to another. Stress is a part of daily life for health professionals such as nurse's, physicians and hospital Administrators.

Nursing is a profession within the health care sector which centers on the care of individuals, families, communities, in order to help them to achieve, preserve or improve the finest health and strengthens the life. Nursing is generally perceived as demanding profession. Along with the increased demand and progress in the nursing profession, stress among the nurses has also increased.

Gray-Toft and Anderson (2012) identified that care of dying patient and death divergence with physicians, insufficient preparation to deal with the emotional needs of patients and their families, inadequate team support, variance with other nurses and supervisors, workload, ambiguity regarding treatment were the major factors of stress. Workload, decreased job sovereignty, inadequate supervisor support, less opportunities of learning on job and inappropriate feedback to be significant predictors of stress among nurses

Stress affects the Cognition which can be manifested in mental slowness, confusion, general negative attitudes or thoughts, constant worry, difficulty concentrating, forgetfulness, difficulty thinking in a logical sequence, the sense that life is overwhelming, unable to solve problem

Emotional signs include irritation, no sense of humor, frustration, jumpiness, over excitability, feeling overworked, feeling overwhelmed, sense of helplessness, apathy. Behavioral signs include decreased contact with family and friends, poor work relations, sense of loneliness, decreased sex drive, avoiding ,failing to set aside times for relaxation through activities such as hobbies, music, art or reading

Stress adjoin the outcomes that make threats to organizational success, including physical injuries at work, absenteeism, turnover, reduced results, diminished job contentment. Depression and sleep difficulty have been reported as frequent stress-related outcomes

Job stress has been associated with reduced job satisfaction, increased psychological agony, physical complaints, and absenteeism. Several studies have found that high levels of job stress contribute to feelings of inadequacy, self-doubt, lower self-esteem, irritability, and somatic disturbance in nurses. As a group, nurses tend to have high rates of transience and unbalanced 
high rates of general illness, stress-related disease, psychiatric outpatient consultation, and psychiatric admissions

\section{NEED FOR THE STUDY}

Job stress is believed to account for approximately $50 \%$ of all workplace absences and for as much as $40 \%$ of employee turnover. In a study conducted by Apeksha Gulavani, Mahadeo Shinde Majority $49 \%$ of nurses had reported frequent occurrence of stress, $30 \%$ reported occasional occurrence of stress, $21 \%$ reported extreme occurrence of stress.

U. Syed Aktharsha, H. Anisa (2011) conducted a study on job stress and job satisfaction among nursing personnel in leading hospital tiruchirapalli.210 respondents participated in this survey. Chi-square test revealed that some factors associated with burnouts and job satisfaction is found to be significant. Multiple regression analysis revealed that some independent variables concerned with job stress, burnouts and job satisfaction are significant in explaining the level of overall job satisfaction of nursing personnel.

Nirmanmoh Bhatia ,et al(2010) conducted a study on occupational stress among nurses in tertiary care hospital central delhi.87 nurses were selected randomly and data was collected by self administered questionnaire $87.4 \%$ of nurses from the sample reported occupational stress. Time Pressure was found to be the most stressful whereas 'Discrimination' was the least stressful of the given possible sources of stress in everyday life. Other highly stressful sources were: handling various issues of life simultaneously with occupation such as caring for own children/parents, own work situation and personal responsibilities. 'High level of skill requirement of the job' was the most important stressor and 'helpfulness of supervisors/senior sisters' was the least significant stressor directly related to nursing profession. Other significant work related stressors were: the fact that their jobs required.

Stress is easily manageable if it is recognized at an early stage. So the investigators took the interest to find out the level of stress among nurses

\section{OBJECTIVES OF THE STUDY}

The present study intends to identify the level of stress among nurses and to associate it with the socio demographic variables

\section{MATERIAL AND METHODS}

A descriptive cross sectional research design was adopted to identify the level of burnout among nurses working in a selected tertiary care hospital, Nellore. 200 nurses were selected by using simple random sampling technique out of 750 nurses working in the hospital. Nurses who were willing to participate in the study were included in the study. Nurses who have attended any training programme related to stress and who are practicing yoga were excluded from the study 


\section{Stress among Nurses in a Tertiary Care Hospital}

\section{Description of the Tool}

The tool used in this study has two sections

Section I deals with the socio demographic variables such as age, gender, marital status, educational qualification, designation, income, area of living, area of working, number of working hours, number of night duties done in a month, support system, coping mechanism used, relaxation technique used, presence of illness and the type of illness.

Section II deals with modified stress inventory which consists of 50 items. The total score is 100. The tool assesses the stress in areas related to work organization, work load, personal and interpersonal relationship at work. The scoring key used is never-0, sometimes- 1 , always-2. The score is interpreted as <33-mild stress, 34-66- moderate stress, 67-100severe stress. Reliability of the tool was established by using test retest method and reliability score is .84 .

\section{Data Collection Procedure}

After obtaining permission from Institutional ethics committee, Medical superintendent and Nursing superintendent data collection was started. Nature and purpose of the study was explained. Informed consent was obtained from the nurses. Modified stress inventory was administered. It took 10-15 minutes for the data collection

\section{Data Analysis}

The data was analyzed by using descriptive and inferential statistics using SPSS 15 version

\section{RESULTS}

Table 1: Frequency and percentage distribution of level of stress among nurses $(N=200)$

\begin{tabular}{|l|l|l|}
\hline Level of Stress & Frequency(f) & Percentage (\%) \\
\hline Mild & 2 & 1 \\
\hline Moderate & 79 & 39.5 \\
\hline Severe & 119 & 59.5 \\
\hline Total & $\mathbf{2 0 0}$ & $\mathbf{1 0 0}$ \\
\hline
\end{tabular}

Table 2: Mean and standard deviation of level of stress among nurses $(N=200)$

\begin{tabular}{|l|l|l|l|}
\hline \multicolumn{1}{|c|}{ VARIABLE } & MEAN & MEDIAN & SD \\
\hline Level of stress & 67.86 & 83 & 12.3 \\
\hline
\end{tabular}


Table 3: Item wise analysis with mean and standard deviation of level of stress among nurses $(N=200)$

\begin{tabular}{|c|c|c|c|c|c|c|c|c|}
\hline \multirow{2}{*}{ ITEMS } & \multicolumn{2}{|c|}{ NEVER } & \multicolumn{2}{|c|}{ SOMETIMES } & \multicolumn{2}{|c|}{ ALWAYS } & \multirow{2}{*}{ MEAN } & \multirow{2}{*}{ SD } \\
\hline & f & $\%$ & f & $\%$ & f & $\%$ & & \\
\hline I have hectic schedule in my work & 52 & 26 & 47 & 23.5 & 101 & 50.5 & 1.245 & 0.842 \\
\hline My job responsibility is clearly told & 6 & 3 & 38 & 19 & 156 & 78 & 1.75 & 0.499 \\
\hline I have to work under lots pressure & 11 & 5.5 & 59 & 29.5 & 130 & 65 & 1.6 & 0.594 \\
\hline $\begin{array}{l}\text { Nurses station is nearly to the } \\
\text { patient side }\end{array}$ & 19 & 9.5 & 57 & 28.5 & 124 & 62 & 1.52 & 0.665 \\
\hline $\begin{array}{l}\text { I have to walk so much to carry out } \\
\text { patient care }\end{array}$ & 15 & 7.5 & 91 & 45.5 & 94 & 47 & 1.4 & 0.625 \\
\hline $\begin{array}{l}\text { All articles and equipments are } \\
\text { available to render patient care }\end{array}$ & 9 & 4.5 & 129 & 64.5 & 62 & 31 & 1.26 & 0.535 \\
\hline I am being assigned with more work & 5 & 2.5 & 105 & 52.5 & 90 & 45 & 1.42 & 0.544 \\
\hline $\begin{array}{l}\text { I am satisfied with the work what i } \\
\text { do }\end{array}$ & 7 & 3.5 & 77 & 38.5 & 116 & 58 & 1.57 & 0.565 \\
\hline $\begin{array}{l}\text { I find difficult to collect reports } \\
\text { from the lab }\end{array}$ & 11 & 5.5 & 109 & 54.5 & 80 & 40 & 1.38 & 0.67 \\
\hline $\begin{array}{l}\text { I do have professional growth in this } \\
\text { organization }\end{array}$ & 16 & 8 & 111 & 55.5 & 73 & 36.5 & 1.39 & 0.64 \\
\hline $\begin{array}{l}\text { My superior find fault with me all } \\
\text { the time }\end{array}$ & 13 & 6.5 & 132 & 66 & 55 & 27.5 & 1.25 & 0.61 \\
\hline I work in the area of my interest & 15 & 7.5 & 84 & 42 & 101 & 50.5 & 1.48 & 0.59 \\
\hline $\begin{array}{l}\text { I feel my colleagues enjoy many } \\
\text { privileges than me }\end{array}$ & 23 & 11.5 & 74 & 37 & 103 & 51.5 & 1.45 & 0.57 \\
\hline $\begin{array}{l}\text { I get adequate support from my } \\
\text { superiors }\end{array}$ & 12 & 6 & 104 & 52 & 84 & 42 & 1.42 & 0.55 \\
\hline $\begin{array}{l}\text { I have many responsibilities, but no } \\
\text { authority }\end{array}$ & 14 & 7 & 114 & 57 & 72 & 36 & 1.35 & 0.53 \\
\hline $\begin{array}{l}\text { I get appropriate guidance from } \\
\text { superiors during crisis }\end{array}$ & 4 & 2 & 98 & 49 & 98 & 49 & 1.54 & 0.565 \\
\hline $\begin{array}{l}\text { I have to deal with many worried } \\
\text { and anxious patients }\end{array}$ & 11 & 5.5 & 99 & 49.5 & 90 & 45 & 1.47 & 0.625 \\
\hline $\begin{array}{l}\text { I get adequate monetary facilities for } \\
\text { the work }\end{array}$ & 21 & 10.5 & 114 & 57 & 65 & 32.5 & 1.3 & 0.67 \\
\hline I work for longer hours in the field & 8 & 4 & 106 & 53 & 86 & 43 & 1.47 & 0.59 \\
\hline $\begin{array}{l}\text { I have enough resources to learn in } \\
\text { my team }\end{array}$ & 12 & 6 & 86 & 43 & 102 & 51 & 1.54 & 0.5 \\
\hline I am satisfied with the pay offered & 83 & 41.5 & 62 & 31 & 55 & 27.5 & 0.96 & 0.49 \\
\hline $\begin{array}{l}\text { I have been assigned to do others } \\
\text { work also }\end{array}$ & 21 & 10.5 & 91 & 45.5 & 88 & 44 & 1.48 & 0.48 \\
\hline I want to be perfect in my work & 16 & 8 & 70 & 35 & 114 & 57 & 1.63 & 0.47 \\
\hline $\begin{array}{lll}\text { The work environment } & \text { is } \\
\text { encouraging and incites learning }\end{array}$ & 14 & 7 & 96 & 48 & 90 & 45 & 1.49 & 0.46 \\
\hline
\end{tabular}


Stress among Nurses in a Tertiary Care Hospital

\begin{tabular}{|c|c|c|c|c|c|c|c|c|}
\hline I have adequate knowledge & 3 & 1.5 & 73 & 36.5 & 124 & 62 & 1.72 & 0.45 \\
\hline $\begin{array}{l}\text { I have no time to pursue games or } \\
\text { leisure activities with friends }\end{array}$ & 15 & 7.5 & 69 & 34.5 & 116 & 58 & 1.62 & 0.45 \\
\hline $\begin{array}{l}\text { I feel my communication with the } \\
\text { patient is good }\end{array}$ & 5 & 2.5 & 80 & 40 & 115 & 57.5 & 1.67 & 0.44 \\
\hline The stress make me behave different & 17 & 8.5 & 113 & 56.5 & 70 & 35 & 1.49 & 0.43 \\
\hline I can handle every situation & 13 & 6.5 & 113 & 56.5 & 74 & 37 & 1.44 & 0.43 \\
\hline I miss my deadlines & 25 & 12.5 & 112 & 56 & 63 & 31.5 & 1.33 & 0.42 \\
\hline $\begin{array}{l}\text { I feel my patient care is good and } \\
\text { adequate }\end{array}$ & 11 & 5.5 & 91 & 45.5 & 98 & 49 & 1.58 & 0.565 \\
\hline I have to work in shift & 11 & 5.5 & 67 & 33.5 & 122 & 61 & 1.7 & 0.45 \\
\hline $\begin{array}{l}\text { I have enough time to meet my } \\
\text { health needs }\end{array}$ & 25 & 12.5 & 102 & 51 & 73 & 36.5 & 1.39 & 0.53 \\
\hline I suffer a low morale & 29 & 14.5 & 114 & 57 & 57 & 28.5 & 1.3 & 0.53 \\
\hline $\begin{array}{l}\text { My colleagues help me to cope with } \\
\text { work stress }\end{array}$ & 17 & 8.5 & 94 & 47 & 89 & 44.5 & 1.52 & 0.665 \\
\hline I am happy with my relationships & 7 & 3.5 & 82 & 41 & 111 & 55.5 & 1.69 & 0.594 \\
\hline $\begin{array}{l}\text { I develop frequent friction between } \\
\text { me \& superior }\end{array}$ & 19 & 9.5 & 111 & 55.5 & 70 & 35 & 1.43 & 0.55 \\
\hline I have time to spend with my family & 42 & 21 & 98 & 49 & 60 & 30 & 1.27 & 0.842 \\
\hline I want to change my workplace & 31 & 15.5 & 97 & 48.5 & 72 & 36 & 1.39 & 0.53 \\
\hline $\begin{array}{l}\text { I am able to adjust with the new } \\
\text { technologies }\end{array}$ & 15 & 7.5 & 105 & 52.5 & 80 & 40 & 1.51 & 0.565 \\
\hline $\begin{array}{l}\text { I am unable to meet my social } \\
\text { demands }\end{array}$ & 31 & 15.5 & 107 & 53.5 & 62 & 31 & 1.35 & 0.53 \\
\hline I can look after my family & 52 & 26 & 95 & 47.5 & 53 & 26.5 & 1.2 & 0.842 \\
\hline $\begin{array}{l}\text { I want to change my residence } \\
\text { because of my jobs }\end{array}$ & 32 & 16 & 92 & 46 & 76 & 38 & 1.42 & 0.55 \\
\hline $\begin{array}{l}\text { I am able to manage the changes in } \\
\text { my life }\end{array}$ & 15 & 7.5 & 106 & 53 & 79 & 39.5 & 1.53 & 0.565 \\
\hline $\begin{array}{l}\text { I feel the facilities are inadequate for } \\
\text { my better job }\end{array}$ & 12 & 6 & 112 & 56 & 76 & 38 & 1.53 & 0.565 \\
\hline $\begin{array}{l}\text { I am able to adjust with the social } \\
\text { events }\end{array}$ & 15 & 7.5 & 95 & 47.5 & 90 & 45 & 1.59 & 0.565 \\
\hline $\begin{array}{l}\text { I am unable to adapt with the sudden } \\
\text { loss }\end{array}$ & 14 & 7 & 113 & 56.5 & 73 & 36.5 & 1.52 & 0.665 \\
\hline $\begin{array}{l}\text { My family helps me to cope with the } \\
\text { work stress }\end{array}$ & 8 & 4 & 93 & 46.5 & 99 & 49.5 & 1.68 & 0.594 \\
\hline $\begin{array}{l}\text { I can't able to adjust with the society } \\
\text { that force me to drift apart from } \\
\text { normal functioning }\end{array}$ & 14 & 7 & 124 & 62 & 62 & 31 & 1.47 & 0.43 \\
\hline I want to modify my life styles & 7 & 3.5 & 115 & 57.5 & 78 & 39 & 1.59 & 0.565 \\
\hline
\end{tabular}


Table 4: Mean and standard deviation on areas of stress $(N=200)$

\begin{tabular}{|l|l|l|}
\hline Areas of stress & MEAN & SD \\
\hline Job design and workload & 1.34 & 0.497 \\
\hline Work organization & 1.751 & 0.839 \\
\hline Personal & 1.52 & 0.6 \\
\hline Interpersonal relationship at work & 1.537 & 0.685 \\
\hline
\end{tabular}

Table 5: Association between level of stress among nurses with their socio demographic variables $(N=200)$

\begin{tabular}{|c|c|c|c|c|c|c|c|}
\hline \multirow[b]{2}{*}{ Socio demographic variables } & \multicolumn{2}{|c|}{ Mild } & \multicolumn{2}{|c|}{ Moderate } & \multicolumn{2}{|c|}{ Severe } & \multirow[t]{2}{*}{$\mathbf{x}$} \\
\hline & (f) & $(\%)$ & (f) & $(\%)$ & (f) & $(\%)$ & \\
\hline \multicolumn{7}{|l|}{ Age in years } & \multirow{4}{*}{$\begin{array}{l}\mathrm{CV}=5.618, \\
\mathrm{TV}=9.49, \\
\mathrm{df}-4, \mathrm{P}<0.05, \mathrm{NS}\end{array}$} \\
\hline $21-30$ & 2 & 1 & 74 & 37 & 117 & 58.5 & \\
\hline $31-40$ & 0 & 0 & 5 & 2.5 & 1 & 0.5 & \\
\hline $41-50$ & 0 & 0 & 0 & 0 & 1 & 0.5 & \\
\hline \multicolumn{7}{|l|}{ Sex } & \multirow{3}{*}{$\begin{array}{l}\mathrm{CV}=2.803, \\
\mathrm{TV}=5.99, \\
\mathrm{df}-2, \mathrm{P}<0.05, \mathrm{NS}\end{array}$} \\
\hline Male & 0 & 0 & 4 & 2 & 14 & 7 & \\
\hline Female & 2 & 1 & 75 & 37.5 & 105 & 52.5 & \\
\hline \multicolumn{7}{|l|}{ Religion } & \multirow{4}{*}{$\begin{array}{l}\mathrm{CV}=1.850, \\
\mathrm{TV}=3.84, \\
\mathrm{df}-4, \mathrm{P}<0.05, \mathrm{NS}\end{array}$} \\
\hline Hindu & 2 & 1 & 44 & 22 & 71 & 35.5 & \\
\hline Muslim & 0 & 0 & 2 & 1 & 2 & 1 & \\
\hline Christian & 0 & 0 & 33 & 16.5 & 46 & 23 & \\
\hline \multicolumn{7}{|l|}{ Marital status } & \multirow{3}{*}{$\begin{array}{l}\mathrm{CV}=3.176, \\
\mathrm{TV}=7.82, \\
\mathrm{df}-2, \mathrm{P}<0.05, \mathrm{NS}\end{array}$} \\
\hline Unmarried & 2 & 1 & 67 & 33.5 & 110 & 55 & \\
\hline Married & 0 & 0 & 12 & 6 & 9 & 4.5 & \\
\hline \multicolumn{7}{|l|}{ Educational Qualification } & \multirow{5}{*}{$\begin{array}{l}\mathrm{CV}=4.673, \\
\mathrm{TV}=12.59, \\
\mathrm{df}-6, \mathrm{P}<0.05, \mathrm{NS}\end{array}$} \\
\hline M.Sc(N) & 0 & 0 & 2 & 1 & 2 & 1 & \\
\hline B.Sc(N) & 2 & 1 & 57 & 28.5 & 100 & 50 & \\
\hline P.B.B.Sc(N) & 0 & 0 & 1 & 0.5 & 1 & 0.5 & \\
\hline GNM & 0 & 0 & 19 & 9.5 & 16 & 8 & \\
\hline \multicolumn{7}{|l|}{ Income } & \multirow{4}{*}{$\begin{array}{l}\mathrm{CV}=18.007, \\
\mathrm{TV}=13.28, \\
\mathrm{df}-4, \mathrm{P}<0.001 \\
\mathrm{~S}^{* * *}\end{array}$} \\
\hline Rs.5000-8000 & 0 & 0 & 35 & 17.5 & 22 & 11 & \\
\hline Rs.8000-11000 & 2 & 1 & 42 & 21 & 96 & 48 & \\
\hline Rs.11000-15000 & 0 & 0 & 2 & 1 & 1 & 0.5 & \\
\hline \multicolumn{7}{|l|}{ Years of experience } & \multirow{4}{*}{$\begin{array}{l}\mathrm{CV}=22.975 ., \\
\mathrm{TV}=22.46, \\
\mathrm{df}- \\
4, \mathrm{P}<0.001, \mathrm{~S}^{* * *}\end{array}$} \\
\hline$<1$ year & 2 & 1 & 35 & 17.5 & 21 & 10.5 & \\
\hline $1-3$ years & 0 & 0 & 42 & 21 & 97 & 48.5 & \\
\hline 3-6 years & 0 & 0 & 2 & 1 & 1 & 0.5 & \\
\hline \multicolumn{7}{|l|}{ Designation } & \multirow{3}{*}{$\begin{array}{l}\mathrm{CV}=0.559, \\
\mathrm{TV}=3.84, \\
\mathrm{df}-2, \mathrm{P}<0.05, \mathrm{NS}\end{array}$} \\
\hline Staff nurse & 2 & 1 & 74 & 27 & 114 & 57 & \\
\hline Ward in charge & 0 & 0 & 5 & 2.5 & 5 & 2.5 & \\
\hline
\end{tabular}




\begin{tabular}{|c|c|c|c|c|c|c|c|}
\hline \multicolumn{7}{|l|}{ Area of working } & \multirow{6}{*}{$\begin{array}{l}\mathrm{CV}=8.565, \\
\mathrm{TV}=15.51, \\
\mathrm{df}-8, \mathrm{P}<0.05, \mathrm{NS}\end{array}$} \\
\hline Ward & 0 & 0 & 39 & 19.5 & 41 & 20.5 & \\
\hline ICU & 2 & 1 & 23 & 11.5 & 45 & 22.5 & \\
\hline HDU & 0 & 0 & 8 & 4 & 18 & 9 & \\
\hline Emergency & 0 & 0 & 4 & 2 & 8 & 4 & \\
\hline OT & 0 & 0 & 5 & 2.5 & 7 & 3.5 & \\
\hline \multicolumn{7}{|l|}{ Area of living } & \multirow{3}{*}{$\begin{array}{l}\mathrm{CV}=8.706, \\
\mathrm{TV}=7.82, \\
\mathrm{df}-2, \mathrm{P}<0.02, \mathrm{~S}^{*}\end{array}$} \\
\hline Rural & 0 & 0 & 14 & 7 & 6 & 3 & \\
\hline Urban & 2 & 1 & 65 & 32.5 & 113 & 56.5 & \\
\hline \multicolumn{7}{|c|}{ Any programme attended related to stress } & \multirow{3}{*}{$\begin{array}{l}\mathrm{CV}=6.754, \\
\mathrm{TV}=6.63, \\
\mathrm{df}-2, \mathrm{P}<0.01, \mathrm{NS}\end{array}$} \\
\hline Yes & 0 & 0 & 9 & 4.5 & 3 & 1.5 & \\
\hline No & 2 & 1 & 70 & 35 & 116 & 58 & \\
\hline \multicolumn{7}{|c|}{ Relaxation technique used } & \multirow{5}{*}{$\begin{array}{l}\mathrm{CV}=8.974, \\
\mathrm{TV}=12.59, \\
\mathrm{df}-6, \mathrm{P}<0.05, \mathrm{NS}\end{array}$} \\
\hline Yoga & 0 & 0 & 4 & 2 & 1 & 0.5 & \\
\hline Meditation & 0 & 0 & 0 & 0 & 1 & 0.5 & \\
\hline Listening to music & 2 & 1 & 72 & 36 & 117 & 58.5 & \\
\hline Play & 0 & 0 & 3 & 1.5 & 0 & 0 & \\
\hline
\end{tabular}

\section{DISCUSSION}

\section{FINDINGS RELATED TO LEVEL OF STRESS}

Table 1 reveals that among 200 samples 2(1\%) had Mild stress, 79(39.5\%) had Moderate stress and $119(59.5 \%)$ had severe stress which is similar to the study conducted by Nirmanmoh bhatia, Jagul kshore, Tanu anand and Ram chander thiloha (2010) which reported the prevalence of occupational stress amongst nurses was $87.4 \%$. Mean of stress is 67.86 , Median of stress is 83 and Standard deviation is 12.3.The present study also emphasis that majority of the nurses are affected with stress

From the item analysis it is clearly evident that majority of the nurses 10(50.5\%) feel they have a hectic schedule of work and it s felt by 130(65\%) work under lots of pressure. Nurses are not happy with the salary received by them $83(41.5 \%)$ is low which is consistent with the findings of Demerouti, Bakker,Nachreiner, and Schaufeli (2000) where low salary is found as a source of stress and low salary was even a greater source of stress when work pressure was high .

Nurses feel that they have to walk a lot for providing care for the patient 94(47\%).It is also felt that more work is assigned to them always 105(52.5\%).For collecting reports of the patient 109(54.5\%) nurses find it difficult due to the reporting system. Superiors are always finding fault with the nurses may be due the expectation and demand. 103(51.5\%) felt that their colleagues enjoy more privileges than them. 114(57\%) wants their work to be perfect which again adds up stress.116 (58\%) find no time to enjoy the games or the leisure activities as identified by C.N.Rawal, Shradha A. Pardeshi (2014) where nurses have physical exertion and no time for leisure or break time it is explicit from table 4 that organizing the work to 
provide patient care is difficult as they spend more time in walking and waiting for the reports to proceed with the further care. Most of them feel that workload is more as there may not be adequate staffs to render patient care which is revealed by the mean score of 1.751. Interpersonal relationship at work is harder and carrying out the responsibilities of personal and professional is becoming harder.

Highest level of stress was found in the age group between 21-30 years which could be due high demands from the organization and it could be beginning stage of their career. Stress is more prevalent among the female gender as nursing is a female dominated profession and the study participants where majority of them were female. It is also identified that unmarried nurses were mostly affected with high level of stress as this could be due to responsibilities they have at personal and professional life. In the years of experience between 1-3 have severe stress which indicates that growing years of experience leads to stress due to the demand and added responsibilities. Nurses working in wards and intensive care unit experience high level of stress.

Nurses living in urban area have high level of stress. Listening to music is the commonly use relaxation technique used by majority of the nurses.

\section{FINDINGS RELATED TO ASSOCIATIO N OF LEVEL OF STRESS AMONG NURSES WITH THEIR SOCIO DEMOGRAPHIC VARIABLES}

In associating the level of stress with the socio demographic variables it is revealed that income and experience have significance at the level $\mathrm{p}<0.001$ and area of living have significance association with the level of stress at the level $\mathrm{p}<0.02$ and variables such as age, gender, religion, marital status, professional education, designation, area of work, programme attended related to stress, relaxation technique used have no significance association with the level of stress at the level of $\mathrm{p}<0.05$ level

\section{CONCLUSION}

The study has identified that majority of the nurses have stress. It is also found that stress due to work organization and inter personal relationship at work is harder which adds up to the stress. It is evident in the present study that younger age group and women were commonly affected with severe stress .Income earned and place where they live also influences the stress. Strengthening the coping mechanism is vital.

\section{RECOMMENDATIONS:}

1. Work area should be arranged in such a way that nurses are easy access to all articles required for patient care

2. Interpersonal relationship among staff nurses and superiors must be improved

3. Stress among nurses can be organized by stress management programmes, skill training for conflict resolution and assertiveness training

4. Scheduling of patient care assignment can reduce the stress experienced due to work 


\section{Stress among Nurses in a Tertiary Care Hospital}

\section{Acknowledgement}

I thank the hospital authorities for permitting to conduct the study, all the nurses who had participated in the study and Ms. Bincymol, Clinical instructor, Narayana Medical college hospital for helping in the process of data collection.

\section{REFERENCES}

Apeksha Gulavani, Mahadeo Shinde, (2012). Occupational Stress and Job Satisfaction among Nurses. International Journal of Science and Research (IJSR) ISSN (Online): 2319-7064 retrieved from

Blegen MA. (1993).Nurses' job satisfaction: a meta-analysis of related variables. Nurses Research, 42, 36-41.

Borda RG, Norman IJ. (1997).Factors influencing turnover and absence of nurses: a research review. International Journal of Nursing Studies, 34,385-394.

Drake CL, Roehers T, Richardson G, Walsh JK, Roth T. (2004). Shift work sleep disorders: Prevalence and consequences beyond that of symptomatic day workers. Sleep, 14531462.

Dr. C.N.Rawal, Ms. Shradha A. Pardeshi Job Stress Causes Attrition among Nurses in Public and Private Hospitals, IOSR Journal of Nursing and Health Science (IOSRJNHS) e-ISSN: 2320-1959.p- ISSN: 2320-1940 Volume 3, Issue 2 Ver. II (Mar-Apr. 2014), PP 42-47 www.iosrjournals.org

Gray-Toft and T.G. Anderson. (1981). "Stress among hospital nursing staff: Its causes and effects", Social Science and Medicine, 15A, 539-647.

Hill house JJ, Adler CM. (1997). Investigating stress effect patterns in hospital staff nurses: Results of a cluster analysis. Social Science Medicine, 45, 1781-1788. http://www.merriam-webster.com/dictionary/stress

Lazarus RS, Folk man S.( 1984). Stress appraisal and coping. New York: Springer, retrieved\ from http://www.ahrq.gov/professionals/clinicians

Marshall NL, Barnett RC. (1993).Variations in job strain across nursing and social work specialties. Journal of Communication Applied Social Psychology, 3,261-271.

Nirmanmoh bhatia ,Jagul kshore,Tanu anand and Ram chander thiloha.(2010) Occupational Stress Amongst Nurses of Two Tertiary Care Hospitals in Delhi Australasian Medical Journal AMJ, 3, 11, 731-738

P.Gray-Toft and T.G.Anderson (1981) "The nursing stress scale: Development of an instrument", International Journal of Behavioral Assessment, 3, 11-23.

U. Syed Aktharsha, H. Anisa,(2011) .Job stress and job satisfaction :an investigation of nursing personnel. 1(1) retrieved from http:/www.jmijitm.com/papers/130245501118-32.pdf

Tanya I. Gelsema, Margot van der Doef, Stan Maes, Simone Akerboom, Chris Verhoeven International Journal of Stress Management 2005, vol 12., no.3, 222-240 retrieved from http://citeseerx.ist.psu.edu/viewdoc/download?doi=10.1.1.542.170\&rep=rep1\&type=pdf 